\title{
HUBUNGAN KONDISI VENTILASI DAN KEPADATAN HUNIAN TERHADAP KEJADIAN ISPA PADA BALITA DI WILAYAH KERJA PUSKESMAS SUKARAYA BATURAJA TIMUR TAHUN 2019
}

\author{
Toto Harto, SKM., M.K.M \\ Akademi Keperawatan - AKPER AL-MA'ARIF BATURAJA \\ E-mail: toto.akper@yahoo.com
}

\begin{abstract}
ABSTRAK
Penduluan: Infeksi Saluran Pernafasan Akut (ISPA) adalah penyakit saluran pernafasan atas atau bawah, biasanya menular, yang dapat menimbulkan berbagai spektrum penyakit ISPA, merupakan salah satu penyebab kesakitan utama pada balita di negara berkembang. ISPA disebabkan juga oleh kondisi ventilasi dan kepadatan hunian yang tidak sesuai dengan peraturan kesehatan RI. Tujuan penelitian: ini untuk mengetahui hubungan ventilasi dan kepadatan hunian terhadap kejadian ISPA pada balita. Penelitian ini dilakukan di kelurahan Sukajadi wilayah kerja UPTD Puskesmas Sukaraya Kecamatan Baturaja Timur. Penelitian ini di lakukan pada bulan Juli 2019. Metode penelitian: ini merupakan penelitian deskriptif analitik dengan pendekatan cross sectional. Penelitian ini menggunakan alat ukur kuesioner. Sampel dalam penelitian ini sebanyak 30 responden. Hasil Penelitian: berdasarkan uji statistic Chi-Square didapatkan bahwa kondisi ventilasi dengan nilai ( $p$ value $=0,000$ ) dan kepadatan hunian dengan nilai ( $p$ value $=0,000$ ) yang berarti ada hubungan yang bermakna antara kondisi ventilasi dan kepadatan hunian dengan kejadian penyakit ISPA.
\end{abstract}

Kata Kunci : Kondisi Ventilasi, Kepadatan Hunian, ISPA, Balita

\section{ABSTRACT}

Bacground: Acute Respiratory Infection $(A R I)$ is an upper or lower respiratory tract disease, usually contagious, which can cause various spectrums of $A R I$, is one of the main causes of illness in children under five in developing countries. $A R I$ is also caused by conditions of ventilation and density of occupancy that are not in accordance with $R I$ health regulations. The purpose of this study: to determine the relationship of ventilation and occupancy density on the incidence of $A R I$ in infants. This research was conducted in the Sukajadi sub-district, the working area of the UPTD Puskesmas Sukaraya, East Baturaja District. This research was conducted in July 2019. Research methods: this is a descriptive analytic study with cross sectional approach. This study uses a questionnaire measuring tool. The sample in this study were 30 respondents. Research Results: Based on the Chi-Square statistical test it was found that the ventilation conditions with a value ( $p$ value $=0,000$ ) and occupancy density with a value ( $p$ value $=0,000$ ) which means there is a significant relationship between ventilation conditions and occupancy density with the incidence of ARI.

Keywords: Condition of Ventilation, Occupancy Density, ARI, Toddler 


\section{PENDAHULUAN}

ISPA adalah infeksi akut saluran pernapasan atas maupun bawah yang disebabkan oleh infeksi jasad renik atau bakteri, virus, maupun reketsia tanpa atau disertai dengan radang parenkim paru (Wijayaningsih, 2013). Infeksi Saluran Pernafasan Akut (ISPA) adalah penyakit saluran pernafasan atas atau bawah, biasanya menular, yang dapat menimbulkan berbagai spektrum penyakit yang berkisar dari penyakit tanpa gejala atau infeksi ringan sampai penyakit yang parah dan mematikan tergantung patogen penyebabnya, faktor lingkungan, dan faktor penjamu (Masriadi, 2017).

ISPA berlangsung sampai 14 hari yang dapat ditularkan melalui air ludah, darah, bersin maupun udara pernafasan yang mengandung kuman. ISPA diawali dengan gejala seperti pilek biasa, batuk, demam, bersin-bersin, sakit tenggorokan, sakit kepala, sekret menjadi kental, nausea, muntah dan anoreksia (Wijayaningsih, 2013). Banyak orang tua yang sering mengabaikan gejala tersebut, sementara kuman dan virus dengan cepat berkembang di dalam saluran pernafasan yang akhirnya menyebabkan infeksi. Jika telah terjadi infeksi maka anak akan mengalami kesulitan bernafas dan bila tidak segera ditangani, penyakit ini bisa semakin parah menjadi pneumonia yang menyebabkan kematian (lkatan Dokter Anak Indonesia, 2015).

Menurut Maryunani (2010) faktor resiko terjadinya ISPA yaitu faktor individu anak, faktor lingkungan dan faktor perilaku. Faktor individu anak meliputi: umur anak, berat badan lahir, status gizi, vitamin A dan status imunisasi. Faktor lingkungan meliputi: pencemaran udara dan perilaku merokok, ventilasi rumah dan kepadatan hunian.

IVentilasi adalah tempat sebagai proses penyediaan udara segar ke dalam dan pengeluaran udara kotor dari suatu ruangan tertutup secara alamiah maupun mekanis. Ventilasi rumah berfungsi untuk proses penyediaan udara segar dan pengeluaran udara kotor secara alamiah atau mekanis. Hal ini berarti keseimbangan $\mathrm{O} 2$ (oksigen) yang diperlukan oleh penghuni rumah tersebut tetap terjaga. Kurangnya ventilasi akan menyebabkan kurangnya $\mathrm{O} 2$ (oksigen) di dalam rumah yang berarti kadar $\mathrm{CO} 2$ (karbondioksida) yang bersifat racun akan meningkat. Tidak cukupnya ventilasi juga akan menyebabkan kelembaban udara di dalam ruangan naik karena terjadinya proses penguapan cairan dari kulit dan penyerapan. Kelembaban ini akan merupakan media yang baik untuk bakteribakteri penyebab penyakit (Notoatmodjo, 2014).

Salah satu bagian rumah yang terabaikan adalah adanya ventilasi dalam kamar tidur. Syarat ventilasi sesuai standar bangunan nasional adalah luas bersih dari jendela atau lubang hawa sekurang-kurangnya $1 / 10$ dari luas lantai ruangan, jendela atau lubang hawa harus meluas ke arah atas sampai setinggi minimal 1,95 meter dari permukaan lantai, dan adanya adanya lubang hawa yang berlokasi di bawah langit-langit sekurangkurangnya $0,35 \%$ luas lantai yang bersangkutan (Mukono, 2015).

Penularan penyakit saluran pernapasan disebabkan karena kuman didalam rumah tidak bisa tertukar dan mengendap sehingga ventilasi diharuskan memenuhi syarat Menkes 1039 RI Nomor RI No.1077/MENKES/PER/V/2011 yakni luas ventilasi minimal $10 \%$ dari luas lantai. Ventilasi rumah memiliki peranan yang sangat penting adalam pertukaran udara dari dan kedalam rumah. Ventilasi adalah proses penyediaan udara segar ke dalam dan pengeluaran udara kotor dari suatu ruangan tertutup secara alamiah maupun mekanis. Tersedianya udara segar dalam rumah atau ruangan amat dibutuhkan 
manusia, sehingga apabila suatu ruangan tidak mempunyai sistem ventilasi yang baik dan over crowded maka akan menimbulkan keadaan yang dapat merugikan kesehatan (Gunawan et al., 1982). Ventilasi yang sehat haruskah memenuhi syarat yatui $10 \%$ dari luas lantai. Kepadatan penghuni Kepadatan penghuni dalam rumah menurut keputusan menteri kesehatan nomor 829/MENKES/SK/VII/1999 tentang persyaratan kesehatan rumah, satu orang minimal menempati luas rumah $8 \mathrm{~m} 2$. Kepadatan penghuni diukur dengan membandingkan luas rumah dengan jumlah penghuni dalam rumah. Kepadatan hunian rumah akan meningkatkan suhu ruangan yang disebabkan oleh pengeluaran panas badan yang akan meningkatkan kelembaban akibat uap air dari pernapasan tersebut. Dengan demikian, semakin banyak jumlah penghuni rumah maka semakin cepat udara ruangan mengalami pencemaran gas atau bakteri yang dapat menggangu kesehatan (ISPA).

Data dari World Health Organization (WHO) menunjukkan angka kematian pada balita di dunia pada tahun 2013 sebesar 45,6 per 1.000 kelahiran hidup dan $15 \%$ diantaranya disebabkan oleh ISPA. Menurut data yang diperoleh dari WHO pada tahun 2012, ISPA atau pneumonia merupakan penyakit yang paling sering diderita oleh balita yaitu sebanyak $78 \%$ balita datang berkunjung ke pelayanan kesehatan dengan kejadian ISPA. Setiap tahun, jumlah balita yang dirawat di rumah sakit dengan kejadian ISPA sebesar 12 juta (Tazinya et al, 2018). Insiden ISPA pada balita di negara berkembang diperkirakan 0,29 anak setiap tahun dan di negara maju sebanyak 0,05 anak setiap tahun. Penyebab kematian akibat ISPA di negara berkembang lebih tinggi dibandingkan negara maju yaitu sebesar 10-50 kali (Ramani et al, 2016).
ISPA pada balita tahun 2014 berkisar antara $20-30 \%$, sedangkan pada tahun 2015 terjadi peningkatan menjadi $63,45 \%$. Data dari Buletin Surveilans ISPA Berat di Indonesia (SIBI) pada tahun 2014 yang dilaksanakan di enam rumah sakit provinsi di Indonesia, didapatkan 625 kasus ISPA berat, 56\% adalah laki-laki dan $44 \%$ adalah perempuan. Sementara kejadian ISPA pada balita di Sumatera Barat tahun 2015 sebanyak 11.326 kasus (22,94\%) dan pada tahun 2016 meningkat menjadi 13.384 kasus $(27,11 \%)$ (Dinkes, 2016).

Berdasarkan prevalensi Infeksi Saluran Pernafasan Akut (ISPA) tahun 2016 di Indonesia telah mencapai 25\% dengan rentang kejadian yaitu sekitar $17,5-41,4 \%$ dengan 16 provinsi diantaranya mempunyai prevalensi di atas angka nasional. Survei mortalitas yang dilakukan oleh Subdit ISPA tahun 2016 menempatkan ISPA sebagai penyebab kematian bayi terbesar di Indonesia dengan persentase $32,10 \%$ dari seluruh kematian balita (Pangaribuan, 2017).

Data Nasional berdasarkan data Riskesdas 2018 kejadian ISPA di Propinsi Sumatera Selatan sekitar 16,69\% (Kemkes RI, 2018). Sedangkan untuk kabupaten Ogan Komering Ulu cakupan penemuan kasus pneumonia tahun 2017 sebesar 60,36\% dari perkiraan jumlah kasus yang ditetapkan (Profil Kesehatan Kab. OKU, 2018). Berdasarkan data puskesmas Sukaraya Infeksi Saluran Pernafasan Akut (ISPA) termasuk sepuluh penyakit terbanyak dimana pada tahun 2016 ditemukan 34,19\% kasus ISPA, tahun 2017 ditemukan 24,51\% kasus dan pada tahun 2018 ditemukan 48,30\%.

\section{METODE PENELITIAN}

Penelitian ini menggunakan metode Deskriptif Analitik dengan pendekatan Cross Sectional dimana peneliti mengukur 
variabel dalam satu sampel populasi yang mewakili populasi penelitian dilaksanakan, artinya tiap subjek penelitian hanya di wawancarai sekali saja dan pengukuran dilakukan terhadap status variabel subjek pada saat pemeriksaan (Notoatmodjo, 2013).

Populasi yang digunakan dalam penelitian ini adalah ibu-ibu yang mempunyai balita (0-5 tahun) di Kelurahan Sukajadi wilayah kerja UPTD Puskesmas Sukaraya. Ibu mempunyai anak balita yang menderita ISPA memeriksakan sakitnya ke UPTD Puskesmas Sukaraya periode Januari-Juni 2019 adalah 143 orang. Dalam penelitian ini untuk mengambil sampel digunakan cara Acedental Sampling yaitu sampel di ambil

secara acak dari seluruh ibu yang memiliki anak balita yang datang ke UPTD Puskesmas Sukaraya. Sampel yang di dapat yaitu sebanyak 30 responden.

Kriteria yang di ambil dari penelitian ini adalah :

a. Ibu-ibu yang mempunyai Balita usia 05 tahun

b. Bisa membaca dan menulis.

c. Apabila responden tidak dapat membaca dan menulis, maka kuesioner akan dibacakan dan di check list oleh peneliti.

d. Bersedia menjadi responden.

HASIL PENELITIAN

\section{Distribusi Hubungan Kondisi ventilasi Dengan Kejadian ISPA}

Tabel.1

Hubungan Kondisi ventilasi Dengan Kejadian ISPA Pada Balita

\begin{tabular}{|c|c|c|c|c|c|c|c|c|}
\hline \multirow[t]{3}{*}{ No } & \multirow[t]{3}{*}{ Kondisi ventilasi } & \multicolumn{4}{|c|}{ Kejadian ISPA } & \multicolumn{2}{|c|}{ Total } & \multirow{3}{*}{$\begin{array}{c}P \\
\text { Value }\end{array}$} \\
\hline & & \multicolumn{2}{|c|}{$\mathrm{Ya}$} & \multicolumn{2}{|c|}{ Tidak } & \multirow[t]{2}{*}{$\mathbf{F}$} & \multirow[t]{2}{*}{$\%$} & \\
\hline & & $\mathbf{F}$ & $\%$ & $\mathbf{F}$ & $\%$ & & & \\
\hline 1 & Tidak Memenuhi Syarat & 15 & 88.2 & 2 & 11.8 & 17 & 100 & \\
\hline \multirow[t]{2}{*}{2} & Memenuhi Syarat & 2 & 15.4 & 11 & 84.6 & 13 & 100 & 0.000 \\
\hline & Total & 17 & 56.7 & 13 & 43.3 & 30 & 100 & \\
\hline
\end{tabular}

Pada tabel.1 menunjukkan bahwa dari 30 responden yang kondisi ventilasi rumahnya tidak memenuhi syarat dan balita terkena ISPA sebanyak 15 responden $(88.2 \%)$ dan rumahnya tidak memenuhi syarat dan ballita tidak terkkena ISPA sebanyak 2 responden (11.8\%) sedangkan kondisi ventilasi yang memenuhi syarat dan anaknya tidak terkena ISPA sebanyak 11 responden $(84.6 \%)$ dan kondisi ventilasi memenuhi syarat dan balita terkena ISPA sebanyak 2 responden (15.4\%). Berdasatkan hasil uji fisher-exact menunjukkan Nilai $P=0,000(P=<0,05)$, sehingga dengan demikian, dapat ditarik kesimpulan bahwa ada hubungan antara kondisi ventilasi rumah dengan kejadian ISPA pada balita di Puskesmas Sukaraya kabepaten OKU. 


\title{
2. Distribusi Hubungan Kepadatan Hunian Dengan Kejadian ISPA
}

Tabel.2

\begin{abstract}
Hubungan Kondisi Kepadatan Hunian Dengan Kejadian ISPA Pada Balita Di Puskesmas Sukaraya Kabupaten OKU
\end{abstract}

\begin{tabular}{ccccccccc} 
No & $\begin{array}{c}\text { Kondisi Kepadatan } \\
\text { Hunian }\end{array}$ & \multicolumn{4}{c}{ Kejadian ISPA } & \multicolumn{2}{c}{ Total } & $\boldsymbol{P}$ \\
& & \multicolumn{2}{c}{ Ya } & \multicolumn{2}{c}{ Tidak } & F & $\%$ & Value \\
& & F & $\%$ & F & $\%$ & & & \\
1 & Tidak Memenuhi Syarat & 12 & 100 & 0 & 0 & 12 & 100 & \\
2 & Memenuhi Syarat & 5 & 27.8 & 13 & 72.2 & 18 & 100 & 0.000 \\
& Total & 17 & 56.7 & 13 & 43.3 & 30 & 100 &
\end{tabular}

Pada table.2 menunjukkan dari 30 kondisi kepadatan hunian tidak memenuhi responden kondisi kepadatan huniannya memenuhi syarat dan balita tidak terkena ISPA sebanyak 13 responden (72.2\%), kondisi kepadatan huniannya memenuhi syarat dan balita terkena ISPA sebanyak 5 responden (27.8\%) sedangkan kondisi tidak memenuhi syarat dan balita terkena ISPA sebanyak 12 responden (100\%) dan

\section{PEMBAHASAN}

Hasil penelitian menunjukkan bahwa ada hubungan antara kondisi ventilasi rumah dengan kejadian ISPA pada balita di Puskesmas Sukaraya. Ventilasi dalam rumah berfungsi sebagai sistem sirkulasi udara atau pertukaran udara dalam rumah karena udara yang segar dalam ruangan sangat dibutuhkan manusia. Ventilasi yang buruk akan menimbulkan gangguan kesehatan pernapasan pada penghuninya (Soekidjo Notoatmodjo, 1997:150). Hasil uji chisquare menunjukkan Nilai $\mathrm{P}=0,000(\mathrm{P}=<$ $0,05)$ maka hasil tersebut dapat ditarik kesimpulan bahwa ada hubungan antara kondisi ventilasi rumah dengan kejadian ISPA pada balita di Puskesmas sukaraya. Hasil ini sejalan dengan hasil penelitian Lindawaty (2010) dalam Munaya (2013) mengatakan bahwa terdapat hubungan antara ventilasi terhadap penyakit ISPA syarat dan balita tidak memenuhi syarat yaitu nihil/tidak ada.Berdasatkan hasil uji fisher-exact menunjukkan Nilai $P=0,000$ $(P=<0,05)$. Kesimpulan bahwa ada hubungan antara kondisi kepadatan hunian dengan kejadian ISPA pada balita di Puskesmas sukaraya kabupaten OKU.

pada anak balita dan resiko anak balita mengalami ISPA 3,07 kali lebih besar pada ventilasi rumah yang tidak memenuhi syarat dibandingkan dengan ventilasi yang memenuhi syarat.

Rumah yang mempunyai ventilasi yang tidak berfungsi dengan baik akan menghasilkan 3 akibat yaitu kekurangan oksigen, bertambahnya konsentrasi $\mathrm{CO} 2$ dan adanya bahan organik beracun yang mengendap dalam rumah. Oleh karena itu, memperoleh udara yang segar menurut Novitasari (2013) dinyatakan bahwa hal itu dapat dilakukan dengan 2 cara yaitu dengan ventilasi alamiah dan ventilasi buatan.

Hal ini sejalan dengan pendapat Notoatmodjo (2007) yang mengatakan bahwa ventilasi rumah harus dibedakan menjadi dua yaitu ventilasi alamiah dan ventilasi buatan. Ventilasi alamiah yaitu dimana aliran udara di dalam ruangan 
tersebut terjadi secara alamiah melalui jendela, pintu, lubang angin, dan lubanglubang pada dinding. Ventilasi alamiah tidak menguntungkan, karena juga merupakan jalan masuknya nyamuk dan serangga lainnya ke dalam rumah. Ventilasi buatan yaitu dengan menggunakan alat-alat khusus untuk mengalirkan udara misalnya kipas angin dan mesin penghisap udara. Namun alat ini tidak cocok dengan kondisi rumah di pedesaan. Ventilasi rumah yang kurang akan lebih memungkinkan timbulnya ISPA pada bayi dan anak balita karena mereka lebih lama berada di rumah sehingga dosis pencemaran tentunya akan lebih tinggi.

$$
\text { Wilayah kerja Puskesmas }
$$

Sukaraya sendiri, berdasarkan pada observasi mendalam terhadap populasi penyebaran penyakit ISPA pada balita di daerah tersebut, peneliti melihat rumahrumah yang ada memang tidak memiliki syarat ventilasi yang cukup untuk menyaring udara yang masuk ke dalam rumah. Kondisi kelembaban yang cukup tinggi di daerah Sukaraya dan sekitarnya tidak dibarengi dengan penyesuaian konstruksi rumah yang ideal dengan syarat kesehatan. Ditambah lagi dengan tingkat kepadatan penduduk dimana rumah-rumah berjejer saling berdekatan membuat suasana menjadi lumayan pengap sehingga bibit-bibit penyakit terperangkap dalam satu ruang dan membuatnya berkembang dengan sangat cepat, baik melalui penularan dari orang ke orang maupun melalui pertumbuhan virus penyakit itu. Dominannya jumlah bayi penderita ISPA di puskesmas Sukaraya yang datang dari populasi rumah dengan syarat kepadatan hunian yang sehat secara klinis memperlihatkan sebuah kondisi actual yang relatif bertentangan dengan teori yang sudah ada.
Sebagaimana dalam uraian terdahulu dijelaskan bahwa kepadatan hunian dalam rumah menurut Keputusan Menteri Kesehatan $\mathrm{RI}$ No.829/Menkes/SK/VII/1999 tentang persyaratan kesehatan rumah, kepadatan hunian ruang tidur minimal luasnya $8 \mathrm{~m} 2$ dan tidak dianjurkan digunakan lebih dari 2 orang kecuali anak di bawah umur 5 tahun. Berdasarkan kriteria tersebut diharapkan dapat mencegah penularan penyakit dan melancarkan aktivitas. Keadaan tempat tinggal yang padat dapat meningkatkan faktor polusi dalam rumah yang telah ada.

Hasil uji chi-square yang menunjukkan Nilai $\mathrm{P}=0,000(\mathrm{P}=<0,05)$ tentunya akan memberikan kesimpulan bahwa ada hubungan antara kondisi kepadatan hunian dengan kejadian ISPA pada balita di Puskesmas sukaraya. Hasil penelitian ini sesuai dengan penelitian yang dilakukan oleh Rudianto (2013) pada balita di 5 posyandu Desa Tamansari Kecamatan Pangkalan Karawang.

\section{KESIMPULAN}

1. Ada hubungan antara kondisi ventilasi dengan kejadian ISPA di Kelurahan Sukajadi wilayah kerja Puskesmas Sukaraya Kabupaten OKU.

2. Ada hubungan antara kepadatan hunian dengan kejadian ISPA di Kelurahan Sukajadi wilayah kerja Puskesmas Sukaraya Kabupaten OKU.

\section{DAFTAR PUSTAKA}

1. Arikunto, Suharsimi Dr. Prof. 2002.Prosedur Penelitian Suatu Pendekatan Praktek. Edisi Revisi V, Rineka Cipta, Jakarta.

2. Direktorat Jenderal Pengendalian Penyakit dan Penyehat Pedoman Pengendalian Infeksi Saluran 
pernapasan Akut. Jakarta :

Kementerian Kesehatan $\mathrm{Rl}$ an

Lingkungan (P2PL)., 2011.

3. Erlien, 2008. Penyakit saluran

Pernapasan, Sunda Kelapa

Pustaka, Jakarta.

4. Ikatan Dokter Anak Indonesia (IDAI). (2014). Pedoman Imunisasi di Indonesia (Edisi kelima). Satgas Imunisasi Ikatan Dokter Anak Indonesia

5. Kemkes RI, 2017.Infeksi saluran Pernafasan akut, http://www.fuadbahsin.wordpress.co $\mathrm{m}$.

6. Kerangka Teori Hubungan Antara Faktor- Faktor Risiko dengan Kejadian ISPA (Sumber: Modifikasi Dinkes RI, 2001; Soekidjo Notoatmodjo, 1997;Srikandi Fardiaz, 1992; Juli Soemirat, 2000; Depkes RI,2001; Kertasapoetra, Marsetyo, Med, 2001; Mukono, 2000; Dinkes Prov. Jateng, 2005; Markum, 2002; I Dewa Nyoman Supariasa, Bachsyar Bakri dan Ibnu Fajar, 2002).

7. Sari, N. L. E., Marlinae, L., \& Noor, F. A. (2016). Hubungan kesehatan rumah tinggal terhadap kejadian pneumonia balita di Desa Sambangan Kecamatan Bati-Bati Kabupaten Tanah Laut. Jurnal Publikasi Kesehatan Masyarakat, 1(1), 34-43.

8. Saryono, 2008.Prosedur Penelitian Suatu Pendekatan Praktek. Edisi Revisi V, Rineka Cipta, Jakarta. 